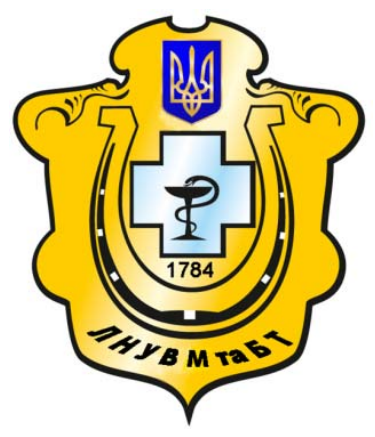

Науковий вісник Львівського національного університету ветеринарної медицини та біотехнологій імені С.3. Гжицького

Scientific Messenger of Lviv National University of Veterinary Medicine and Biotechnologies named after S.Z. Gzhytskyj

doi:10.15421/nvlvet7721

ISSN 2518-7554 print

ISSN 2518-1327 online

$\underline{\text { http://nvlvet.com.ua/ }}$

УДК 619:616.98-074:578.833.31

\title{
Поширеність африканської чуми свиней в Україні
}

\author{
В.В. Глебенюк, О.Г. Глебенюк, В.Г. Петруша \\ hlebeniuk.v.v@dsau.dp.ua
}

\begin{abstract}
Дніпропетровський державний аграрно-економічний університет,
\end{abstract} вул. Ворошилова, 25, м. Дніпро, 49600, Украӥна

\begin{abstract}
Складна епізоотична ситуація щеоо африканської чуми свиней (АЧС) зумовлює необхідність ретельного ветеринарносанітарного контролю на кордоні та проведення відповідних карантинних заходів. Поступове розщирення нозоареалу АЧС в Україні значно ускладнює систему контролю та ерадикаиії хвороби на державному рівні. Метою намої роботи було визначення поширеності АЧС в Украӥні за 2012-2016 рр. Під час досліджень використовували епізоотологічний метод. 3а 2012 рік в Україні було зареєстровано один спалах АЧС. Наступні спалахи хвороби були відмічені у 2014 р. на території 10 районів 3 областей. Упродовж 2015 року випадки АЧС відмічено у 27 раніше благополучних районах. У 2016 р. АЧС встановлено у 38 раніше благополучних районах. Упродовж 2012-2016 рр. в Украӥні вільними від збудника хвороби лишалися 6 області: Львівська, Івано-Франківська, Тернопільська, Херсонська, Дніпропетровська та Донеиька. Найбільшу кількість районів, на території яких були зареєстровані спалахи АЧС, відмічено у Чернігівській, Одеській, Полтавській та Миколаївській областях. За досліджуваний період спалахи АЧС зафіксовано у 28 прикордонних районах, що межують із Білоруссю, Російською Федераиією, Молдовою, Угорщиною та Румунією. Територія анексованого Криму з 2013 р. вважається зоною стійкого неблагополуччя з АЧС. Таким чином, упродовж 2012-2016 років АЧС зареєстровано на території 91 адміністративного району 18 областей Украӥни.
\end{abstract}

Ключові слова: африканська чума свиней, поширеність, територія Украӥни, прикордонні райони, спалах хвороби.

\section{Распространенность африканской чумы свиней в Украине}

\author{
В.В. Глебенюк, Е.Г. Глебенюк, В.Г. Петруша \\ hlebeniuk.v.v@dsau.dp.ua
}

Днепропетровский государственный аграрно-экономический университет, ул. Ворошилова, 25, г. Днепр, 49600, Украина

\begin{abstract}
Сложная эпизоотическая ситуация по африканской чуме свиней (АЧС) вызывает необходимость тщательного ветеринарно-санитарного контроля на границе и проведения соответствующих карантинных мероприятий. Постепенное расширение нозоареала АЧС в Украине значительно усложняет систему контроля и эрадикации болезни на государственном уровне. Целью нашей работы было определение распространенности АЧС в Украине за 2012-2016 г2. Во время исследований использовали эпизоотологический метод. За 2012 год в Украине была зарегистрирована одна вспышка АЧС. Следующие вспышки болезни были отмечены в 2014 на территории 10 районов 3 областей. В течение 2015 случаи АЧС отмечено в 27 ранее благополучных районах. В 2016 г. АЧС установлено в 38 ранее благополучных районах. В течение $2012-$ 2016 гг. в Украине свободными от возбудителя болезни оставались 6 областей: Львовская, Ивано-Франковская, Тернопольская, Херсонская, Днепропетровская и Донеикая. Наибольшее количество районов на территории которых были зарегистрированы вспышки АЧС отмечено в Черниговской, Одесской, Полтавской и Николаевской областях. За исследуемый период вспьики АЧС, зафиксированы в 28 пограничных районах, граничащих с Беларусью, Российской Федерацией, Молдовой, Венгрией и Румынией. Территория аннексированного Крыма с 2013 г. считается зоной устойчивого неблагополучия по АЧС. Таким образом, в течение 2012-2016 годов АЧС зарегистрировано на территории 91 административного района 18 областей Украиньл.
\end{abstract}

Citation:

Glebenyuk, V.V., Glebenyuk, O.G., Petrusha, V.G. (2017). The african swine fever spread in Ukraine. Scientific Messenger LNUVMBT named after S.Z. Gzhytskyj, 19(77), 92-95. 
Ключевые слова: африканская чума свиней, распространенность, территория Украины, пограничные районы, вспышка болезни.

\title{
The african swine fever spread in Ukraine
}

\author{
V.V. Glebenyuk, O.G. Glebenyuk, V.G. Petrusha \\ hlebeniuk.v.v@dsau.dp.ua \\ Dnipropetrovsk state agro-economic university, \\ Voroshilov Str., 25, Dnepr, 49600, Ukraine
}

\begin{abstract}
The dangerous epizootic situation of african swine fever (ASF) necessitates a thorough veterinary control at the border and related quarantine measures. The gradual expansion nosological area ASF in Ukraine complicates the system control and eradication of the disease at the state level. The aim of our work was to determine the prevalence of ASF in Ukraine for 2012-2016 years. During the research used epizootological method. According to 2012 in Ukraine were registered one outbreak of ASF. Next outbreaks were recorded in 2014 on the territory of 10 districts of three regions. Over 2015 cases of ASF noted in 27 previously advantaged districts. In 2016 ASF is set in 38 previously advantaged districts. During the 2012-2016 years in Ukraine free from disease 6 remained region: Lviv, Ivano-Frankivsk, Ternopil, Kherson, Dnipropetrovsk and Donetsk. The greatest number of districts in the territory which have been reported outbreaks of ASF was observed in Chernihiv, Odessa, Poltava and Mykolaiv regions. Over the period ASF outbreaks recorded in 28 border districts bordering the Belarus, Russia, Moldova, Hungary and Romania. The territory annexed Crimea from 2013 is considered stable zone trouble of the ASF. Thus, during the years 2012-2016 ASF registered in the territory of 91 administrative district 18 regions of Ukraine.
\end{abstract}

Key words: african swine fever, spread, the territory of Ukraine, the border areas, outbreak disease.

\section{Вступ}

Африканська чума свиней (АЧС) набула значного поширення в Південній та Екваторіальній Африці, в таких країнах, як Ангола, Бенін, Заїр, Замбія, Мозамбік, Південно-Африканська Республіка. 31970 р. спалахи АЧС реєструвалися на американському континенті: Кубі (1971, 1980), Бразилії (1978), Домініканській Республіці (1978), Гаїті (1979). В Свропі хвороба вперше з'явилась у Португалії (1957), потім в Іспанії (1960), Франції (1964), Італії (1967), СРСР (1977), Бельгії (1985), Нідерландах (1986). 31999 р. європейські країни було оздоровлено від АЧС (крім о. Сардинія, Італія) (Nedosekov and Makarov, 2010; Sytiuk and Obrazhei, 2012).

Трансконтинентальне занесення збудника АЧС спричинило спалахи хвороби в Грузії (2007) і подальше розповсюдження територією Кавказького регіону (Абхазії, Південної Осетії, Арменії, Азербайджану, Нагорному Карабаху), Російської Федерації, Білорусії, України, країн Балтії (Латвії, Литви, Естонії), Польщі (Stehnii et al., 2012; Guinat et al., 2016).

Складна епізоотична ситуація щодо АЧС, яка icнує сьогодні в світі, зумовлює необхідність ретельного ветеринарно-санітарного контролю на кордоні та проведення відповідних карантинних заходів. Поступове розширення нозоареалу АЧС в Україні значно ускладнює систему контролю та ерадикації хвороби на державному рівні. Тому оцінка широти розповсюдження АЧС на території України залишається актуальною.

Мета роботи: визначити поширеність африканської чуми свиней в Україні.

\section{Матеріал і методи досліджень}

Використовували результати наукових публікацій, повідомлень МЕБ, інтернет-ресурсів (www.asf.vet.ua, www.vet.gov.ua, www.fsvps.ru) та здійснювали аналіз епізоотичних даних за 2012-2016 pp.

\section{Результати та їх обговорення}

За 2012 рік в Україні було зареєстровано один спалах АЧС в Приморському районі Запорізької області. Наступні спалахи хвороби були відмічені у 2014 р. на території 10 районів 3 областей: Луганської (3), Чернігівської (6) та Сумської (1).

Упродовж 2015 року випадки АЧС відмічено у 27 раніше благополучних районах. Серед них: 5 районів Київської області, 7 - Чернігівської, 1 - Рівненської, 1 - Житомирської, 4 - Сумської, 3 - Полтавської, 2 Одеської, 3 - Миколаївської та 1 - Черкаської (табл.).

Як видно 3 табл., станом на 2016 р. АЧС встановлено у 38 раніше благополучних районах: у Полтавській області - 6, Кіровоградській - 4, Одеській - 10, Хмельницькій - 5, Сумській - 2, Чернівецькій - 1, Миколаївській - 7, Черкаській - 2, Рівненській - 3, Волинській -2 , Вінницькій -1 , Харківській -6 , Житомирській - 1, Закарпатській - 1, Київській - 2 .

Упродовж 2012-2016 рр. в Україні вільними від збудника хвороби залишалося 6 областей: Львівська, Івано-Франківська, Тернопільська, Херсонська, Дніпропетровська та Донецька. За цей період вірус АЧС виявлено в 91 адміністративному районі 18 областей (рис.).

Найбільшу кількість районів, на території яких були зареєстровані спалахи АЧС, відмічено у Чернігівській області - 13 із 22 районів, Одеській - 12 із 26 , Полтавській - 9 із 25 та Миколаївській - 10 із 19.

Варто зазначити, що за досліджуваний період спалахи АЧС зафіксовано у 28 прикордонних районах, що межують із Білоруссю, Російською Федерацією, Молдовою, Угорщиною та Румунією. Так, у 2014 р. хворобу зареєстровано у Станично-Луганському, Біловодському та Краснодонському районах Луганської області; Сновському (Щорському), Корюківсько- 
му, Городнянському та Ріпкинському районах Чернігівської області; Середино-Будському районі Сумської області. У 2015 р. вірус виявлено у НовгородСіверському та Чернігівському районах Чернігівської області; Глухівському районі Сумської області; Іванківському районі Київської області, Дубровицькому районі Рівненської області. У 2016 р. АЧС зафіксовано у Кілійському, Болградському, Беляївському, Окнянському та Роздільнянському районах Одеської області; Новоселицькому районі Чернівецької області; Любешівському та Ратнівському районах Волинської області; Зарічненському районі Рівненської області;
Сумському та Білопільському районах Сумської області; Дергачівському, Харківському та Вовчанському районах Харківської області, Виноградівському районі Закарпатської області. Це свідчить про динамічну небезпеку транскордонного поширення АЧС.

Територія анексованого Криму з 2013 р. вважається зоною стійкого неблагополуччя 3 АЧС. Випадки захворювання підтверджено як у дикої фауни, так i свійських тварин.

Динаміка поширеності АЧС в розрізі областей України за 2012-2016 рр.

Таблицяя

\begin{tabular}{|l|c|c|c|c|}
\hline \multirow{2}{*}{ Області } & \multicolumn{2}{|c|}{ Кількість районів*, на території яких були зареєстровані випади АЧС, за роками } \\
\cline { 2 - 5 } & 2012 & 2014 & 2015 & 2016 \\
\hline Запорізька & $1 / 1$ & $0 / 0$ & $0 / 0$ & $0 / 0$ \\
\hline Луганська & $0 / 0$ & $3 / 3$ & $0 / 0$ & $0 / 0$ \\
\hline Чернігівська & $0 / 0$ & $6 / 6$ & $8 / 7$ & $4 / 2$ \\
\hline Сумська & $0 / 0$ & $1 / 1$ & $4 / 4$ & $2 / 2$ \\
\hline Київська & $0 / 0$ & $0 / 0$ & $5 / 5$ & $4 / 3$ \\
\hline Рівненська & $0 / 0$ & $0 / 0$ & $1 / 1$ & $2 / 1$ \\
\hline Житомирська & $0 / 0$ & $0 / 0$ & $1 / 1$ & $8 / 6$ \\
\hline Полтавська & $0 / 0$ & $0 / 0$ & $3 / 3$ & $71 / 10$ \\
\hline Одеська & $0 / 0$ & $0 / 0$ & $2 / 2$ & $2 / 2$ \\
\hline Миколаївська & $0 / 0$ & $0 / 0$ & $3 / 3$ & $4 / 4$ \\
\hline Черкаська & $0 / 0$ & $0 / 0$ & $1 / 1$ & $5 / 5$ \\
\hline Кіровоградська & $0 / 0$ & $0 / 0$ & $0 / 0$ & $1 / 1$ \\
\hline Хмельницька & $0 / 0$ & $0 / 0$ & $0 / 0$ & $2 / 2$ \\
\hline Чернівецька & $0 / 0$ & $0 / 0$ & $0 / 0$ & $1 / 1$ \\
\hline Волинська & $0 / 0$ & $0 / 0$ & $0 / 0$ & $6 / 6$ \\
\hline Вінницька & $0 / 0$ & $0 / 0$ & $0 / 0$ & $1 / 1$ \\
\hline Харківська & $0 / 0$ & $0 / 0$ & $0 / 0$ & $62 / 53$ \\
\hline Закарпатська & $0 / 0$ & $0 / 0$ & $0 / 0$ & $28 / 27$ \\
\hline
\end{tabular}

Примітка: чисельник - загальна кількість неблагополучних районів, знаменник - кількість уперше зареєстрованих неблагополучних районів

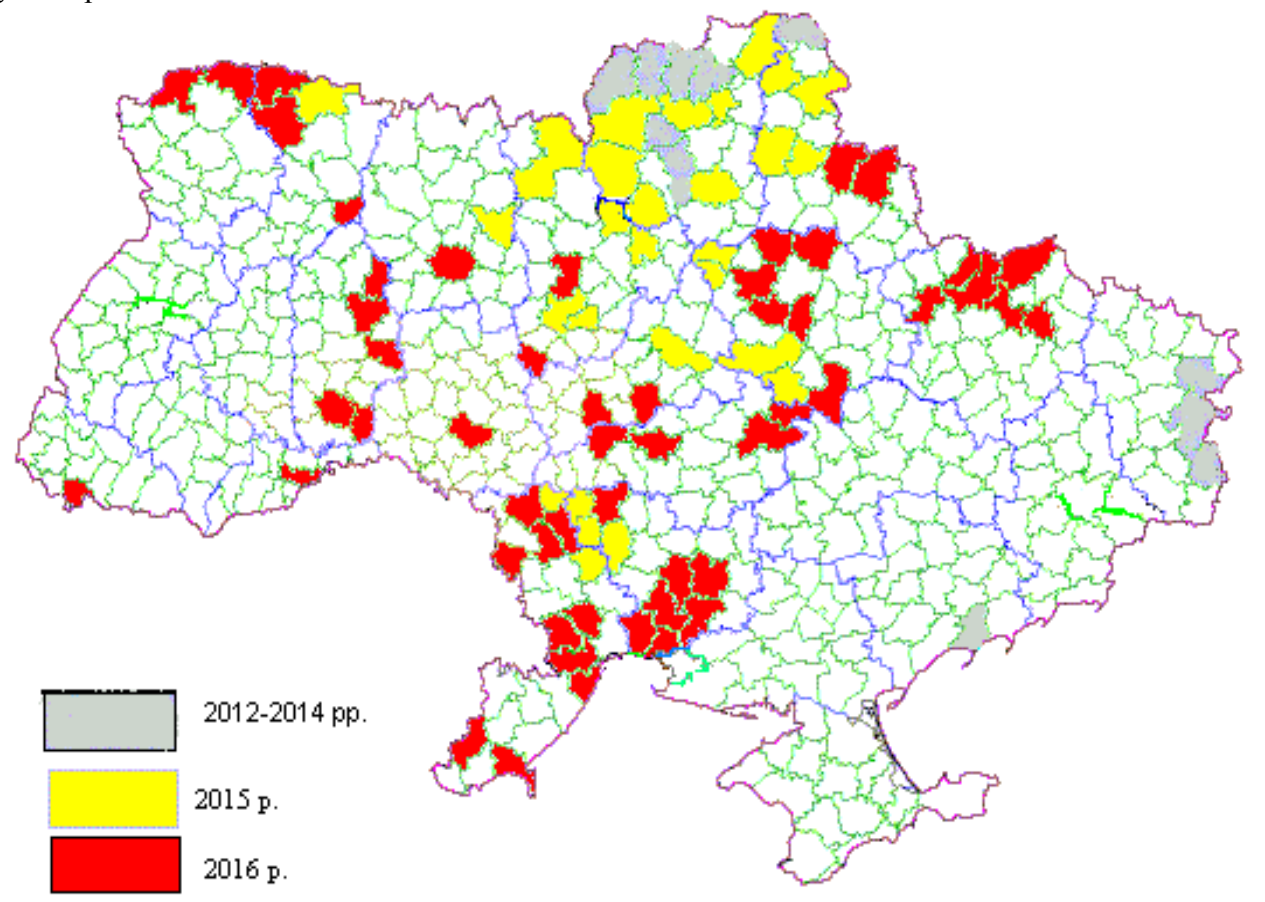

Рис. Карта-схема поширення АЧС в України за фактом ресстрації неблагополучних районів (2012-2016 pp.) 


\section{Висновки}

Впродовж 2012-2016 років африканську чуму свиней зареєстровано на території 91 адміністративного району 18 областей України, у тому числі 28 прикордонних районах, що межують із Білоруссю, Російською Федерацією, Молдовою, Угорщиною та Румунією.

Перспективи подальших досліджень полягають у розробці епізоотологічного прогнозу АЧС в Україні на 2017-2018 pp.

\section{Бібліографічні посилання}

Nedosekov, V.V., Makarov, V.V. (2010). Mizhnarodna klasyfikatsiia khvorob i osoblyvo nebezpechni infektsii tvaryn. K. (in Ukrainian).
Sytiuk, M.P., Obrazhei, A.F. (2012). Istorychni ta epizootolohichni aspekty afrykanskoi chumy svynei. Veterynarna medytsyna Ukrainy. 1, 9-12 (in Ukrainian).

Stehnii, B.T., Buzun, A.I., Horilovych, A.P. (2012). Naukovyi suprovid monitorynhu afrykanskoi chumy svynei v Ukraini. Veterynarna medytsyna Ukrainy. 9, 20-25 (in Ukrainian).

Guinat, C., Gogin, A., Blome, S. (2016). Transmission routes of african swine fever virus to domestic pigs: current knowledge and future research directions. Veterinary Record. 178, 262-267.

Стаття надійшла до редакиії 21.03.2017 